\title{
Red cell aplasia in myelodysplastic syndrome
}

\author{
P J Williamson, D G Oscier, A J Bell, T J Hamblin
}

Department of

Haematology, Royal

Victoria Hospital,

Bournemouth

P J Williamson

D G Oscier

A J Bell

T J Hamblin

Correspondence to:

Dr P J Williamson,

Department of Haematology,

Southampton General

Hospital, Tremona Road,

Southampton

Accepted for publication

21 November 1990

\begin{abstract}
Six cases of red cell aplasia occurring in patients with myelodysplastic syndromes (MDS) showed a diversity of clinical course and prognosis. In some patients red cell aplasia may have represented an evolution of MDS while in others autoimmune destruction of erythoblasts may have been the mechanism. A proliferative phase is seen in many of these patients, the clinical importance of which is uncertain.
\end{abstract}

Red cell aplasia (RCA) is a rare disorder characterised by a profound reduction in erythroblasts in the bone marrow. It may be a congenital disorder (Diamond-Blackfan syndrome) or acquired in association with an underlying disease. Of the acquired group, the most common disease associations are with thymoma, viral infections (especially parvovirus), connective tissue disorders and malignancy. ${ }^{1}$ In many cases it is possible to show that RCA results from humoral or $T$ cellmediated suppression of erythroid progenitors. Occasional reports have documented the occurrence of RCA in patients with $\mathrm{MDS},{ }^{2-5}$ but it is unknown whether RCA has an autoimmune aetiology or whether it is a manifestation of clonal changes in the bone marrow.

\section{Case reports}

In a series of 360 cases of MDS studied at this hospital over a 10 year period we identified six cases where RCA was observed for at least part of the duration of follow up. RCA is difficult to define in the context of myeloid hyperplasia but all our patients were transfusion dependent and had bone marrows containing $1 \%$ or fewer erythroblasts. Details of the six cases are given in the table.

\section{Discussion}

The clinical course of cases 1-3 differs greatly from that seen in cases 4-6. In cases 1-3 RCA was associated with an increasing percentage of blasts in the marrow. Cases 2 and 3 also had a proliferative phase (rising peripheral blood platelet, neutrophil, and monocyte counts) prior to an increase in blast cells in the marrow. All three patients died within a short time of the development of RCA and increasing blast percentage in the marrow. The mechanism of RCA in these cases is presumably due to an intrinsic defect of maturation and proliferation of erythroid precursors as part of the myelodysplastic disorder.

In cases 4-6 there was no evidence of proliferative or blastic change; in these patients RCA may have a different, and possibly autoimmune, aetiology. This is particularly suggested by case 4 who became transfusion independent after a short course of prednisolone, having had four weekly transfusions for the preceding five months. We did not look for evidence of recent parvovirus infection but the time course of changes in clinical and

Course in six patients with $M D S$ and $R C A$

\begin{tabular}{|c|c|c|c|c|c|}
\hline \multirow{3}{*}{ Case No } & \multirow{3}{*}{$\frac{\text { Age/sex }}{82 / \mathrm{F}}$} & \multicolumn{3}{|l|}{ Bone marrow } & \multirow{3}{*}{$\begin{array}{l}\text { Clinical outcome } \\
\text { Died of sepsis (11m) }\end{array}$} \\
\hline & & \multirow{2}{*}{$\begin{array}{l}\text { At presentation } \\
\text { RAEB } \\
\text { Blasts } 9 \% \\
\text { Erythroblasts } 10 \%\end{array}$} & \multicolumn{2}{|c|}{ Subsequently (time from diagnosis) } & \\
\hline & & & $(10 \mathrm{~m})$ & $\begin{array}{l}\text { RAEB } \\
\text { Blasts } 17 \% \\
\text { Erythroblasts } 1 \%\end{array}$ & \\
\hline 2 & $78 / F$ & $\begin{array}{l}\text { RARS } \\
\text { Erythroblasts } 34 \%\end{array}$ & $\begin{array}{l}(25 \mathrm{~m}) \\
(53 \mathrm{~m})\end{array}$ & $\begin{array}{l}\text { RARS } \\
\text { Erythroblasts 34\% } \\
\text { RAEB } \\
\text { Blasts 8\% } \\
\text { Erythroblasts 1\% }\end{array}$ & Died of sepsis $(56 m)$ \\
\hline 3 & $81 / F$ & $\begin{array}{l}\text { CMML } \\
\text { Blasts 2\% } \\
\text { Erythroblasts }<1 \%\end{array}$ & $(2 \mathrm{~m})$ & $\begin{array}{l}\text { CMML } \\
\text { Blasts 12\% } \\
\text { Erythroblasts 3\% }\end{array}$ & Died of blastic transformation $(7 \mathrm{~m})$ \\
\hline 4 & $74 / M$ & $\stackrel{\text { RA }}{\text { Erythroblasts }<1 \%}$ & $(7 \mathrm{~m})$ & $\underset{\text { Erythroblasts } 37 \%}{\text { RA }}$ & $\begin{array}{l}\text { Transfusion independent following steroid } \\
\text { treatment; alive and well }(22+\mathrm{m})\end{array}$ \\
\hline 5 & $58 / F$ & $\stackrel{\text { RA }}{\text { Erythroblasts } 1 \%}$ & $(6 \mathrm{~m})$ & RA & $\begin{array}{l}\text { Remains transfusion dependent; alive and well } \\
(28+\mathrm{m})\end{array}$ \\
\hline 6 & $87 / M$ & RA & $(5 \mathrm{~m})$ & RA & Died of unrelated causes $(9 \mathrm{~m})$ \\
\hline
\end{tabular}

RA-refractory anaemia; RAEB - refractory anaemia with excess blasts; RARS—refractory anaemia with ringed sideroblasts; CMML-chronic myelomonocytic leukaemia. 
marrow response would not support such a hypothesis. Antibody-mediated RCA is known to occur in chronic granulocytic leukaemia $^{6}$ but it is difficult to show in MDS because of poor or absent growth in vitro of erythroid progenitors, even in those patients with plentiful erythroblasts. ${ }^{7}$ Autoimmune phenomena, however, are common in patients with $\mathrm{MDS} .{ }^{8}$ Consequently those patients who have RCA and no excess of blasts may have a relatively good prognosis and should be considered for immunosuppressive treatment.

Four previous case reports of MDS and RCA have described a proliferative phase at the time of, or soon after, the onset of RCA. ${ }^{23}$ One of these cases also had an excess of blasts and all four had a relatively good prognosis. Two out of three treated with prednisolone showed at least a partial recovery of erythropoiesis. A transient response to prednisolone was also seen in a further case of chronic myelomonocytic leukaemia with RCA. ${ }^{5}$ This patient developed acute leukaemia within five months of diagnosis. Taken together with our six cases there seems to be a spectrum of disease in which autoimmune RCA may be superimposed on MDS, the latter showing a tendency to evolve to acute leukaemia over a very variable time course. The relevance of a proliferative element in these cases is unclear.
Thrombocytosis is a feature of the 5q-syndrome $^{9}$ (a subgroup within MDS), and many of these patients have a degree of erythroid hypoplasia. It is debatable, however, whether such patients should be considered in the same spectrum of disease as those described above.

1 Ammus SS, Yunis AA. Acquired pure red cell aplasia. Am J Hematol 1987;24:311-26.

2 Craig A, Geary CG, Love EM, Lin-Yin J. Red cell hypoplasia, thrombocytosis and leucocytosis: myelodysplastic and proliferative syndrome. J Clin Pathol 1988; 41:1168-70.

3 Cook MK. Red cell hypoplasia associated with myeloproliferative and myelodysplastic syndrome. J Clin Pathol 1988;42:890-1.

4 Boulton-Maggs PHB, Galloway MJ, Rhodes EGH. Pure red cell aplasia heralding chronic myelomonocytic leukaemia. Clin Lab Haematol 1989;11:61-5.

5 Lopez-Guillermo A, Cervantes F, Sacanella E, Florensa L, Rozman C. Pure red cell aplasia associated with chronic myelomonocytic leukaemia. Clin Lab Haematol 1989;11: 410-1.

6 Dessypris FN, McKee CL, Metantonakis C, Teliacos M, Krantz SB. Red cell aplasia and chronic granulocytic

7 Oscier DG, Worsley A, Darlow S, Figes A, Williams JD, Hamblin TJ. Correlation of bone marrow colony growth in the myelodysplastic syndromes with the FAB classification and the Bournemouth score. Leuk Res 1989;13:833-9.

8 Mufti GJ, Figes A, Hamblin TJ, Oscier DG, Copplestone JA. Immunological abnormalities in myelodysplastic syndromes. I. Serum immunoglobulins and autoantibodies. Br J Haematol 1986;63:143-7.

9 Kerkhofs H, Hagemeijer A, Leeksma CHW, et al. The 5qchromosome abnormality in haematological disorders. $\mathrm{Br}$ J Haematol 1982;52:365-81.
Servicio de Anatomía Patologica, Hospital Civil De Bilbao, 48013 Bilbao, Spain

J I López

J Alfaro

Departamento de Anatomía Patológica, Hospital 12 de

Octubre, Madrid,

Spain

C Ballestin

Correspondence to:

Dr J I López

Accepted for publication

21 November 1990

\author{
J I López, J Alfaro, C Ballestin
}

\begin{abstract}
Two cases of undifferentiated carcinomas of the major salivary glands were studied using immunohistochemical techniques. Results showed that this entity was a high grade malignant neoplasm arising from the excretory duct. Despite the undifferentiated appearance multiple immunophenotypes were evident in both cases.
\end{abstract}

Well defined, undifferentiated carcinomas of salivary glands are fairly uncommon high grade neoplasms. ${ }^{12}$ These tumours arise in major salivary glands, mainly in the parotid. ${ }^{2}$ Despite the fact that the light microscopic features are undifferentiated, ${ }^{1}$ electron microscopic studies have shown glandular or neuroendocrine features in some of them. ${ }^{2}$

In an attempt to detect differentiating features we recently studied two cases using immunohistochemistry.

\section{Case reports}

CASE 1

A 54 year old man presented with a tumour mass on the left side of his neck. The lesion had grown quickly over two months. Ipsilateral subdigastric lymph node metastases were also detected on physical examination. Lumpectomy and lymphadenectomy were performed. Macroscopically, the tumour measured $6 \mathrm{~cm}$ and showed multiple haemorrhagic foci. He died of metastatic disease three months later.

CASE 2

A 60 year old man presented with a large, left sided tumour mass on his neck. The tumour measured $12 \mathrm{~cm}$. Bilateral lymph node metastases on the lower neck were detected. Palliative surgical resection was performed. Macroscopically, there were multiple haemorrhagic foci with necrotic areas. Death followed rapidly. A post mortem examination was not performed.

In both cases metastatic disease from skin, lung, and gastrointestinal tract was ruled out as far as possible.

Both tumours were located in the parotid gland, and morphologically, fulfilled the light microscopic criteria of undifferentiated carcinomas of major salivary gland. Small or inter- 